\title{
Late Antique Textiles
}

\author{
Amandine Mérat
}

Excavations led between 1903 and 1905 by Arthur C. Mace in cemeteries N 2000 and $\mathrm{N} 2500$ at Naga ed-Deir resulted in the discovery of thousands of burials, divided in Mace's notes into two groups based on their dates. Amongst the so-called Coptic tombs - in opposition to the Egyptian (or Dynastic) tombsapproximately forty-four graves provided textiles, either garments, sackcloth or furnishing items, used or reused in the preparation of the dead for the afterlife. ${ }^{1}$ Although many of the artifacts from these cemeteries were shipped to the University of California, Berkeley, there is no indication that the Coptic textiles were sent there. They are only known today thanks to Mace's manuscript, excavation notebooks, and a few pictures and drawings made at the time of discovery. Based on the sources listed above, this chapter aims to give an overview of the textiles discovered at Naga ed-Deir, their context of production, use and reuse, and excavation, as well as, where possible, an attempted identification of the items described by Mace and his team.

\section{The Collection: Discovery and Sources}

Excavation directed by Mace at Naga ed-Deir between 1903 and 1905 resulted in the discovery of hundreds of textiles. Those included in this study come from approximately forty-four tombs, recorded in excavation notebooks and Mace's manuscript as "Copts," in opposition to the dynastic burials identified as "Egyptians." 2

Approximately forty-nine individuals were found in these graves, mainly simple pits and a few reused Fifth-Twelfth Dynasty rock-cut tombs. The deceased were mostly buried on their own, except for three tombs where an adult was buried with one or two children and, in another tomb, where two children

1 Called mummies by Mace, even if he himself added a note in his manuscript to mention that "The term 'mummy' is misleading, but there is no other word available for a wrappedup burial." The words dead, deceased, or bodies will be used in this publication instead of mummies.

2 The tombs studied here are N 200o-2009, 2130, 2133-2134, 2201, 2203, 2215, 2410, 2413-2416, 2438, 2503-2504, 2611-2613, 2616, 2631-2637, 2700, 2806, 2810-2813, 2830, 2833, 2836, 2839. 
were buried together. ${ }^{3}$ Eighteen individuals could be identified as adult males, ten as adult females, ten as adult of undetermined gender, and eleven as children (babies and children up to ten years old).

Thanks to the exceptional discovery in a child's grave of cemetery $\mathrm{N} 2000$ of a coin minted in year three of the reign of Justinian (529 CE), the gravesand therefore, the textiles found in them-can be contextually dated to the mid-fifth to the sixth century CE. At the time, a period most commonly known today as Late Antiquity, Egypt had been a province of the Roman Empire since the defeat of Cleopatra VII against Octavius in $31 \mathrm{BCE}$, and was ruled from Constantinople since its scission in $395 \mathrm{CE} .{ }^{4}$

Amongst the Roman traditions adopted by Egyptians from the second century onwards, two can explain the increase in number and diversity of textiles found in burial contexts after that date. Indeed, while they progressively abandoned mummification to bury their dead in their daily clothes, head- and footwear, and wrapped into utilitarian or furnishing textiles reused as shrouds, Egyptians also adopted Roman fashion and its most common item of clothing for men, women, and children alike, the tunic. ${ }^{5}$

Mace's description of the textiles discovered in the Late Antique burials varies from a simple listing to an intensive description supported by drawings and, in a few cases, pictures. He himself divided the finds into two main categories: the wrapping textiles and the shirts (or tunics), while he also recorded any headwear - such as hairnets or circlets—and textile accessories—such as a bag and a bandage - found on or near the deceased. Descriptions of the textiles were made by Mace and his team as the bodies were discovered and/or unwrapped. ${ }^{6}$ Therefore, they mostly follow the same model, starting with the outside layer of cloth used to wrap the dead to finishing with the inner one, in direct contact with the body.

Thanks to such consistency, and despite the textiles' absence today and a slight difference between Mace's and contemporary textile terminology, it was possible to identify most of the items Mace was looking at, but also to translate his words into today's most commonly used terms, in order to get a

3 For the adult buried with children, see $\mathrm{N} 2215, \mathrm{~N} 2612$, and N 2414. For two children buried together, see $\mathrm{N} 2504$.

4 For more information regarding the origin and meaning of the word "Copt," see Rutschowscaya and Bénazeth (2000, 28).

5 For more information on clothing and furnishing textiles in the first millennium CE, see Mérat (2015).

6 If unwrapping mummies was a rule in the nineteenth-early twentieth centuries, this practice has been abandoned and is even forbidden in most countries where studies are being held and bodies preserved. For more information on the topic, see Taylor and Antoine (2014, 11-21). 
better understanding and overview of the Late Antique textiles discovered in Cemeteries N 2000 and $\mathrm{N} 2500$ at Naga ed-Deir in 1903-05.

\section{Overview and Attempted Identification of the Textiles Excavated at Naga ed-Deir}

Amongst the forty-four burials excavated by Mace and his team that preserved textiles, six were excluded from this study as cloths found in them were in too poor of a condition to be identified or studied, both in 1903-1905 and in 2019. ${ }^{7}$ The remaining thirty-eight tombs provided a total of more than sixty-five shirts, a hundred and ten wrapping cloths and nine remains of headgear, an attempted overview of which will be given here. ${ }^{8}$

Although not included in the following study, the discovery of these items also bear mention: a textile bag of red cloth, a bandage made from an old shirt, a textile folded into a bandage and tied around the waist of a small glass bottle, and also a few weaving tools (carding comb and spinning wheels) (Fig. 10.1). ${ }^{9}$

\section{3 \\ Garments}

Bodies excavated by Mace were commonly buried with one to three tunics (called "shirts" by Mace), either worn by the deceased or covering the body. Sixty-five were identifiable in Mace's notes and recorded in this study, presenting different techniques of production, weaving, and elements of decoration.

The deceased were most of the time buried with one, sometimes two, plain tunics in undyed linen and/or colored wool, and one or more decorated and more elaborated tunic. ${ }^{10}$ The latter category consists of T-shaped tunics in linen and/or wool, woven in plain weave and/or tapestry, in one or three pieces depending on their desired length. ${ }^{11}$ Neck-openings, when preserved,

$7 \quad \mathrm{~N} 2007, \mathrm{~N} 2414, \mathrm{~N}_{2} 631, \mathrm{~N}_{2} 632, \mathrm{~N} 2810$, and N 2813.

8 Almost all of the burials also contained padding cloths. As they were most of the time only briefly mentioned by Mace, they could not be counted nor recorded with certainty here and were therefore left out of this study. They mostly consisted of old, plain shirts reused to cover the head or fill in areas such as the neck before the wrapping.

$9 \quad$ For the textile bag, see $\mathrm{N}$ 2201; bandage: $\mathrm{N} 2134$ (especially drawing (ii)); textile wrapping a bottle: $\mathrm{N} 2636$; weaving tools: $\mathrm{N} 2049$. For the weaving tools, see also NED-C-846o, 8461.

10 See, for example, the yellow shirt found in N 2201. For a possible comparison, see Manchester T.1994-135 (Pritchard 2006, 10; Hubert 2019, 86, fig. 2).

11 For an example of a tunic woven in one piece, see $\mathrm{N}$ 2001, drawing (iv), and Mace's description: "Remains of linen shirt with embroidered rosettes round sleeves, reaching 


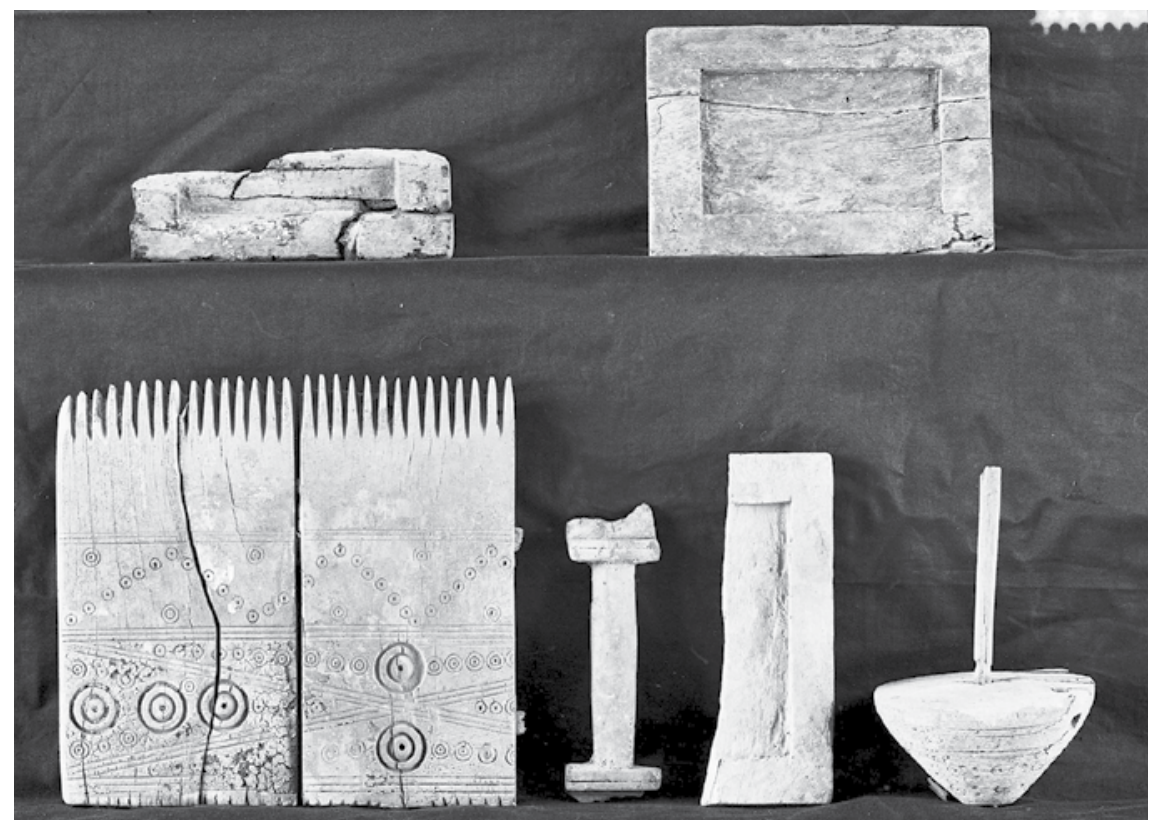

FIGURE 10.1 Weaving tools from N 2049 (NED-C-8462; see drawings in Tomb Catalogue $\mathrm{N} 2049(\mathrm{i})-(\mathrm{v}))$

were mostly cut in a round shape on one or both sides. ${ }^{12}$ A child's tunic also preserved a knot of cloth sewn as a button, probably to adjust the garment once put on, while the neck-opening of another child's tunic was framed on each side by two small sort-of-braids in red wool, made by two lines of chain stitches embroidered at an angle. ${ }^{13}$

apparently to halfway between knee and ankle. 3 woven ridges down each breast and over shoulder [shoulder bands in tapestry, or clavi]. Sides of shirt and bottom of sleeves corded [possibly corded ending and starting borders of shirt]. Shirt made in 1 piece [T-shaped tunic woven in one piece, starting with one sleeve, then the body, and finishing with the second sleeve, before the shirt is folded and sewn on the sides, under the arms] [...] Sleeves were sewn up to above elbow." For an example of a tunic made of three pieces (i.e., two square pieces sewn at front and back to the upper T-shape part of the garment, thus creating a tuck there), see $\mathrm{N} 2009$ (v) and N 2636 (ii). For the record, Mace mistakenly identified similar tunics as "made up of two pieces of cloth, a straight join coming at the waist" in $\mathrm{N} 2611$ and $\mathrm{N} 2636$. For more information on T-shape tunics, see Kwaspen (2019, 228-231), Kwaspen (2014), and Verhecken-Lammens (1992, 29-36).

12 See, for example, $\mathrm{N} 2002$ (vi), $\mathrm{N} 2005$ (vi), $\mathrm{N} 2503$ (i), N 2613 (i), and $\mathrm{N} 2812$ (iii) and (iv). For a possible comparison, see Manchester T.8360, T.8361 (Pritchard 2006, 88-90).

13 For the tunic with knot of cloth, see N 2616. For a possible comparison with a later child's tunic, see Manchester T.9885 (Pritchard 2006, 20-22). For the tunic framed by "braids" 
The tunics mostly have long sleeves, either woven at the same time as the body or sewn to it later. ${ }^{14}$ They were decorated with varied inwoven or applied ornaments located on the shoulders, wrists, knees, and bottom of the garment. ${ }^{15}$ Decoration usually consisted of tapestry and also white, blue, and/ or red brocaded ribbons (identified by Mace as strips with geometrical patterns embroidered or sewn), separately woven and sewn around the opening, the wrists, and/or the bottom of the garment. ${ }^{16}$ Self-banding in the weft direction (called ridges or lines of thicker thread in the woof (weft) by Mace) and flying thread brocading (identified by Mace as needlework or embroidery sewn on or worked into the warp) were also found. ${ }^{17}$

Ornaments consist of shoulder bands (clavi) of different lengths (breast to ankle length) and shapes (simple straight bands, bands ending with medallions or leaf-shaped motifs, or bands made of several isolated motifs called drawn work by Mace). ${ }^{18}$ Most elaborated tunics also bear orbiculi (circular

of red wool, see N 2002 (ix). For possible comparisons, see Coll. Fondation Roi Baudouin FT 3 (Mérat and Quertinmont 2019, 92-93, cat. 72) and Manchester T.8374 (Pritchard 2006, 98-99).

14 For the former, see $\mathrm{N} 2009$ (v) and N 2636 (ii). For the latter, see N 2002 (v).

15 See, for example, N 2002 (iv) and (vi): tunic with applied and sewn bands on the shoulders and at the bottom and sides. For more information on tunic and shawl ornaments, their shapes and distribution, see Rutschowscaya (1990, 151). For possible comparisons, see Coll. Fondation Roi Baudouin FT 74 (Mérat and Quertinmont 2019, 248-249, cat. 225), Pushkin KT 572 (Lechitskaya 2010, 125), and Coll. Fondation Roi Baudouin FT 132 (Mérat and Quertinmont 2019, 250-251, cat. 227).

16 See, for example, N 2002: "Above this, the body was wrapped in [a] shirt [with] elaborate embroidery (vii): Remains of white and blue strip sewn around neck, 2 wide, and around bottom of sleeves. Around bottom of shirt, remains of a strip approx. 7 wide. On this bottom strip at any rate, white and blue were put on separately. White was sewn on so (viii), and blue thread was afterwards worked in such a way as to leave geometrical patterns in white." See also N 2133 (i) and N 2812 (iii). For possible comparisons, see Lyon MT 2013.o.57 (Calament and Durand 2013, cat. 128) and Coll. Fondation Roi Baudouin FT 136 (Mérat and Quertinmont 2019, 252-253, cat. 231).

17 For self-banding, see $\mathrm{N} 2002$ (viii); $\mathrm{N}_{2636}$ and description as follows in N 2003: “[...] The body was clothed in 3 linen shirts, all plain except middle one, which had a decoration of 2 inwoven blue lines of thread." For a possible comparison, see Manchester T.1994-132 (Pritchard 2006, 72, fig. 4.20(b)). For flying thread brocading, see N 2002 (vii) and N 2130 (ii)-(iv). For examples of flying thread brocading on furnishing textiles, see Krefeld 11768 (Paetz gen. Schieck 2003, 45) and Louvre $\mathrm{AF}_{5} 884$ (Rutschowscaya 1990, 24).

18 For clavi, see $\mathrm{N} 2002$ (iv) and (vi); N 2004 (iv); N 2005 (v); and N 2637 (i). For possible comparisons, see BM EA 72491 (Moor 2010, 35, 38, fig. 5) and вM EA 18198. For bands ending in medallions or leaf-shaped motifs, see N 2004 (v); N 2005 (v); N 2009 (vi) and (vii); N 2134 (iii); $\mathrm{N} 2613$ (i); $\mathrm{N} 2636$ (ii) and (iii); and N 2637 (i). For possible comparisons, see KN DM 121 (Moore 1993, 230) and Coll. Fondation Roi Baudouin FT 121 (Mérat and Quertinmont 2019, 128-129, cat.120). For bands made of isolated motifs, see N 2130 
ornaments called medallions or rosettes by Mace), and/or single, double, or triple wrists bands. ${ }^{19}$ Iconography on them is representative of the period's taste and consists of geometric (lines, bands, waving motifs, etc.), floral and vegetal (rosettes, vegetal interlacing called scroll flower type by Mace, etc.), animal (quadrupeds and birds) and figural (dancing figures and putti) motifs. ${ }^{20}$

\section{$4 \quad$ Wrapping Cloths}

According to Mace's notes, over one hundred wrapping cloths were identified and recorded. The deceased were wrapped in up to six layers of textiles, separated by Mace into two categories: sackcloths and shawls (possibly utilitarian and furnishing items, respectively, reused as shrouds in funerary context). ${ }^{21}$

Textiles called sackcloths by Mace are simple, plain coarse textiles (possibly reused utilitarian textiles, such as ship sails, for example), sometimes fringed and decorated with bands of openwork near the ends. ${ }^{22}$

Items described by Mace as shawls are more varied and can be divided into three categories according to his descriptions. The first category comprises

(ii)-(iv); $\mathrm{N} 2812$ (iii); and $\mathrm{N} 2830$ (i). For possible comparisons, see Lyon MT 24400.512 (Calament and Durand 2013, 156-157) and Coll. Fondation Roi Baudouin FT 167, FT 168, and FT 170 (Mérat and Quertinmont 2019, 136-137, cat. 132).

19 For orbiculi, see N 2005 (v); N 2009 (v); N 2134 (iii); N 2613 (i); and N 2636 (ii) and (iv). For wrist bands, see N 2009 (v); N 2134 (iii); N 2415 (ii); and N 2636 (ii) and (v). For possible comparisons, see VAM T.49-1917, Cleveland 1914.527, and Coll. Fondation Roi Baudouin FT 181 (Mérat and Quertinmont 2019, 100-101, cat. 84).

$20 \quad$ For geometric motifs, see N 2700 (i). For a possible comparison, see n. 24, BM EA 72491. For floral and vegetal motifs, see N 2130 (ii)-(iv); N 2133 (i); and N 2830 (i). For the socalled scroll flowers, see a possible comparison in Rassart-Bebergh $(1976,24-25), \mathrm{n}^{\circ} 7$; Coll. Fondation Roi Baudouin FT 30 (Mérat and Quertinmont 2019, 104-105, cat. 9o), and for an iconographic parallel, see Brussels, Musée Royaux d'Art et d'Histoire E.8o66 (Mérat and Quertinmont 2019, 52-53, cat. 44). For animal motifs, see N 2410 (i) and N 2636 (iii) and (v). For a possible comparison, see Coll. Fondation Roi Baudouin FT 66 (Mérat and Quertinmont 2019, 280-281, cat. 264). For figural motifs, see N 2637 (i) and description as follows in $\mathrm{N}$ 2612: "on each side of front and back of shirt, there was a medallion of coloured wool [...]. On medallion, two dancing figures and cherubs [putti] above." For possible comparisons with dancing figures, see Coll. Fondation Roi Baudouin FT 80 (Mérat and Quertinmont 2019, 42-43, cat. 28) and vam T.141-1922. For possible comparisons with putti figures, see Krefeld 12471 (Paetz gen. Schieck 2003, 72) and Pushkin KT 561 (Lechitskaya 2010, 238).

21 See, for example, $\mathrm{N} 2700$ and $\mathrm{N} 2836$.

$22 \mathrm{~N} 2009, \mathrm{~N} 2201, \mathrm{~N} 2413, \mathrm{~N} 2416, \mathrm{~N} 2438, \mathrm{~N} 2812$, and N 2830. For an image of the textile in N 2416, see NED-B-7102. For possible comparison, see Coll. Fondation Roi Baudouin FT 191-1 (Mérat and Quertinmont 2019, 170-171, cat. 140). 


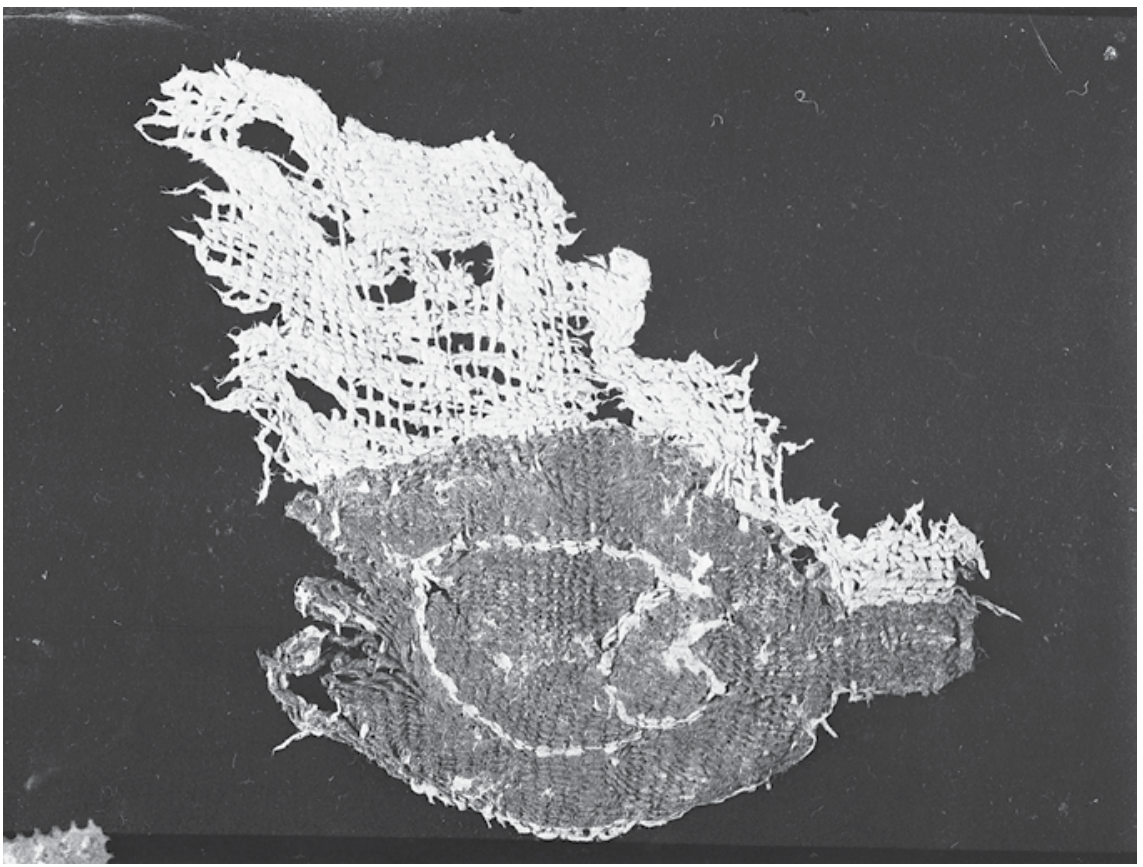

FIGURE 10.2 Rosette from N 2003 (NED-C-7979)

cloths, sometimes fringed or tasseled, of varying workmanship, woven in colored wool (yellow, red, green, etc.). Their decoration, located near the ends and at the corners of the cloths, consists of multicolor geometric patterns (lines, triangles, stars, etc., in white, black, red, etc.) made in brocade (or supplementary brocaded wefts, called embroidery, needlework, or sewn-in patterns by Mace). ${ }^{23}$

The second category comprises a group of cloths, often fringed, woven in plain weave or tapestry, and bearing a geometric decoration covering either the whole surface of the fabric or near its ends only, and made of inwoven lines in either or both directions. ${ }^{24}$

Finally, the third category is made of large pieces of textiles, also fringed in some cases, possibly woven in linen plain weave and/or woolen tapestry, with

$23 \mathrm{~N} 2001$ (ii); 2004 (iii); N 2005, cloths 2), 3), head pad, and drawings (ii)-(iv); N 2009, $\mathrm{N} 2130, \mathrm{~N} 2133, \mathrm{~N} 2413, \mathrm{~N} 2504, \mathrm{~N} 2616, \mathrm{~N} 2633, \mathrm{~N} 2636, \mathrm{~N} 2700, \mathrm{~N} 2830$, and $\mathrm{N} 2836$. For a possible comparison, see Coll. Fondation Roi Baudouin FT 156 (Mérat and Quertinmont 2019, 170-171, cat.141).

24 For decoration covering the entire fabric, see N 2003 (unfinished textile), N 2130, N 2611, $\mathrm{N} 2636$ (plaid shawl), $\mathrm{N} 2833$, and $\mathrm{N} 2836$. For decoration only near the ends, see $\mathrm{N} 2005$, $\mathrm{N} 2215, \mathrm{~N} 2438$, and N 2806 . 


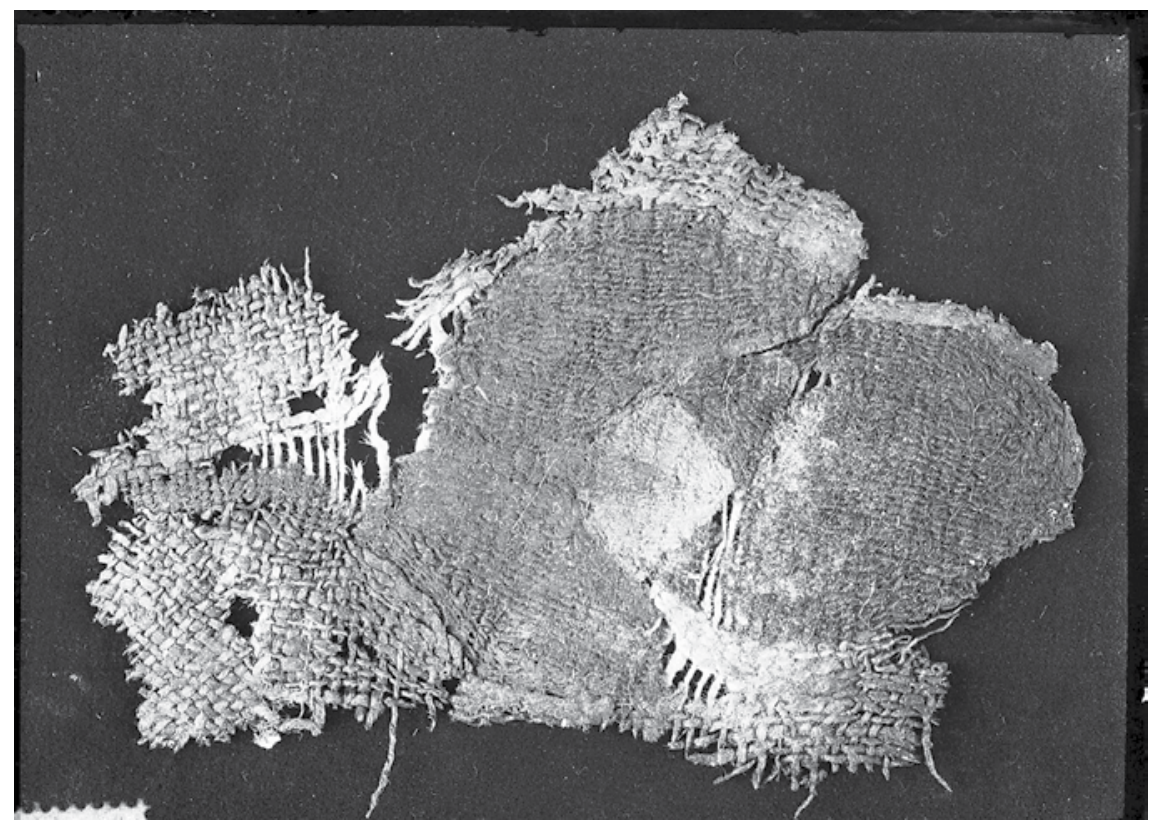

FIGURE 10.3 Rosette from N 2003 (NED-C-7981)

a decoration made of geometric, floral and vegetal (trees, flowers baskets, fourpetaled flowers called rosette by Mace, heart-shaped flowers, leaf-shaped motifs), animal (quadrupeds or birds), and figural motifs, located at the corners and/or covering the whole surface of the fabric (Figures 10.2-3) ${ }^{25}$

25 For geometric motifs, see $\mathrm{N} 2413$ (ii); $\mathrm{N} 2503$ (ii); N 2612 (i); $\mathrm{N} 2806$ (i)-(iv); $\mathrm{N} 2812$ (i); $\mathrm{N} 2839$ (i). For floral and vegetal motifs, see $\mathrm{N} 2203$ (i); N 2613 (iii); N 2812 (i). For trees, see $\mathrm{N}$ 2005. For possible comparisons, see Private Collection (Mérat and Quertinmont 2019, 48-49) and VAM 2162-19oo. For flower baskets, see N 2006 (ii). For a possible comparison, BM EA 29771 (Mérat 2015, 106, cat. 104), VAM 373-1895, and Coll. Fondation Roi Baudouin FT 146 (Mérat and Quertinmont 2019, 46-47, cat. 35). For rosettes, see N 2003 (ii), N 20o6, and N 2413. For N 2003, see also NED-C-7980, 7982. For possible comparisons, BM EA 29771 (Mérat 2015, 106, cat. 114) and Coll. Fondation Roi Baudouin FT 197 and FT 198 (Mérat and Quertinmont 2019, 144-145, cat. 139). For heart-shaped flowers, see N 2006 (ii). For possible comparisons, BM EA 29771 (Mérat 2015, 106, cat. 114). For leaf-shaped motifs, $\mathrm{N} 2134$ (i) and N 2215 (unnumbered drawing). For possible comparisons, Lyon MT 49189, мт 51398.28, and мт 2013.0.19 (Calament and Durand 2013, 162-163), Chemnitz Ko 169 (Mössinger and Metz 2018), and Manchester T.8564 (Pritchard 2006, 124). For birds, see $\mathrm{N} 2006$ (ii). For possible comparisons, see Louvre E 28307, E 28314, E 28723, and E 29302 (Rutschowscaya 1990, 94-95) and вм EA 29771 (Mérat 2015, 106, cat. 114). For figural motifs, see $\mathrm{N} 2203$ (i). See especially N 2130 (i). Based on Mace's drawing, the human figure in the centre of the tabula (square ornament) could be identified as an allegory of the personification of Earth, Gaia, or one of the Four Seasons. For more information on Allegories 
Drawings made by Mace allow one to identify these textiles as possible furnishing textiles (such as covers or hangings), reused as shrouds in a funerary context.

\section{5}

\section{Headgear}

Very few headgear, eight in total, were found on or close to the deceased in the tombs studied here. Amongst these, six were hairnets (called net cap or hood by Mace) in colored wool. ${ }^{26}$ Two were found in children's burials and four in women's graves. ${ }^{27}$ Two circlets were also excavated, one in a child's burial, the other in a man's grave. ${ }^{28}$ Both were made of palm tree leaves wound by red wool threads or fabrics.

Although the Coptic garments went missing during the twentieth century, Mace's rigor in precisely and carefully recording any textile item discovered in $\mathrm{N} 2000$ and $\mathrm{N} 2500$, at a time where most archaeologists, in search of the most beautiful dynastic artifacts, were sending to Europe only the most colorful, cutout elements of textiles with no or limited archaeological context, represents a precious and rare resource permitting one nonetheless to identify the finds excavated in $1903^{-} \mathrm{O} 5$.

Dated to the mid-fifth to the sixth century, thanks to the exceptional discovery in the cemetery of a coin from year three of the reign of Justinian, the Naga ed-Deir textiles are representative of the textile production, fashion, and taste in Late Antique Egypt. Indeed, mostly woven in linen and wool plain weave, tapestry, or brocade, they consist of tunics, headgear, shawls, and furnishing items reused in a funerary context, richly decorated with bands, medallions, and varied patterns bearing geometric, vegetal, floral, animal, and figural motifs mostly inherited from classical imagery.

of the Earth and the Four Seasons, see Mérat (2010). For possible thematic comparisons, see Louvre AF 5982 (Rutschowscaya and Bénazeth 200o, cat. 57) or Manchester T.1968.252 and T.1968.253 (Pritchard 2006, 30-31).

26 For possible comparisons, see KN KTN 816-O3 (Moor and Fluck 2011, 84) and Nantes D 2001.2.3 (Durand and Saragoza 2002, 126).

27 For the former, see $\mathrm{N} 2002$ and N 2504. For the latter, see $\mathrm{N} 2201, \mathrm{~N} 2203, \mathrm{~N} 2636$, and $\mathrm{N} 2811$.

28 For the former, see $\mathrm{N}$ 2006. For the latter, see N 2134. 


\section{Bibliography}

Calament, F. and M. Durand, eds. 2013. Antinoé, à la vie, à la mode: visions d'élégance dans les solitudes. Lyon.

Durand, M. and F. Saragoza, eds. 2002. Égypte, la trame de l'Histoire: textiles pharaoniques, coptes et islamiques. Rouen.

Hubert, B. 2019. "Textiles de Kellis, un village de la période romaine dans l'Oasis de Dakhla." In De Lin et de laine. Textiles égyptiens du $7^{e r}$ millénaire, edited by A. Mérat and A. Quertinmont, 76-83. Brussels.

Kwaspen, A. 2014. "L'importance de l'analyse des techniques et de la connaissance des objets pour la conservation des textiles archéologiques." In KBR-APROA Bulletin 1/201:24-32.

Kwaspen, A. 2019. "Quelques fragments de tuniques de la collection Fill-Trevisiol." In De Lin et de laine. Textiles égyptiens $d u{ }_{1}{ }^{e r}$ millénaire, edited by A. Mérat and A. Quertinmont, 228-233. Brussels.

Letchitskaya, O. 2010. Coptic Textiles. The Pushkin State Museum of Fine Art. Moscow.

Martiniani-Reber, M. 1991. Tissus coptes: Musée d'Art et d'Histoire de Genève. 2 vols. Geneva.

Mérat, A. 2010. Les Allégories de la Terre et des Saisons: des sources littéraires et iconographiques gréco-romaines aux textiles égyptiens d'époque byzantine. Mémoire de Recherche en Histoire de l'Art et Archéologie, Ecole du Louvre. Unpublished, available upon request at l'Ecole du Louvre, Palais du Louvre.

Mérat, A. 2015. "Clothing and Soft Furnishings." In Egypt: Faith after the Pharaohs, edited by C. Fluck, G. Helmecke, and E. R. O'Connell, 214-221. London.

Mérat, A. and A. Quertinmont, eds. 2019. De Lin et de laine. Textiles égyptiens du ${ }^{e r}$ millénaire. Brussels.

Moor, A. De. 1993. Koptisch textiel uit Vlaamse privé-verzamelingen. Zottegem.

Moor, A. De. 2010. "Radiocarbon Dating and Dye Analysis of Roman Linen Tunics and Dalmatics with Purple Coloured Design." Archaeological Textiles Newsletter 51:34-47.

Moor, A. De and C. Fluck, eds. 2011. Dress Accessories of the 1st Millennium AD from Egypt. Tielt.

Mössinger, I. and K. Metz, eds. 2018. Ägyptische Textilien aus spätantiker und frühislamischer Zeit im Bestand der Kunstsammlungen Chemnitz. Bielefeld.

Paetz gen. Schieck, A. 2003. Aus Gräbern geborgen, Koptische Textilien aus eigener Sammlung. Krefeld.

Pritchard, F. 2006. Clothing Culture: Dress in Egypt in the First Millennium AD. Clothing from Egypt in the Collection of the Whitworth Art Gallery. Manchester.

Rassart-Debergh, M. 1997. Textiles d'Antinoé (Égypte) en Haute Alsace. Donation E. Guimet. Colmar. 
Rutschowscaya, M.-H. 1990. Coptic Fabrics. Paris.

Rutschowscaya, M.-H. and D. Bénazeth, eds. 200o. L'art copte en Égypte: 2000 ans de christianisme. Paris.

Taylor, J. and D. Antoine, eds. 2014. Ancient Lives, New Discoveries: Eight Mummies, Eight Stories. London.

Verhecken-Lammens, C. 1992. "Opzetboorden bij Koptische Weefsels." Vlaamse Vereniging voor Oud en Hedendaags Textiel VVOHT Bulletin, 29-36. 